\title{
PENGARUH STRUKTUR MODAL, UKURAN PERUSAHAAN, DAN PROFITABILITAS TERHADAP NILAI PERUSAHAAN OTOMOTIF YANG TERDAFTAR DI BEI PERIODE 2012 -2016
}

\author{
Rahima Yahdi, Aminar Sutra Dewi \\ Sekolah Tinggi Ilmu Ekonomi KBP \\ m2gcompany@gmail.com
}

\begin{abstract}
Automotive companies suffered a loss due to a decrease in sales caused by high taxes and the proliferation of manufacturing components. The purpose of this study is to determine the effect of capital structure on value of company, Company size on value of company and profitability on value of company of IDX period 2012-2016, with 6 companies using purposive sampling method. Method of analysis used was multiple linear regression analysis.The result of the research shows that the capital structure do not have positive and significant influence to company value, and company size do not have positive and significant influence to company value while profitability has an effect on company value. This shows that high profitability influences company value in the eyes of investors.
\end{abstract}

Keywords: capital structure, company size, profitability,company's value

\section{PENDAHULUAN}

Kembang tumbuh industri otomotif saat ini sangat pesat, ditandai dengan terus bertambahnya jumlah kendaraan. Banyaknya jenis kendaraan yang terjual dipasaran berasal dari kepercayaan konsumen pada perusahaan otomotif ternama, perusahaan-perusahaan otomotif ini terus melakukan inovasi-inovasi baru dan kreatif, perkembangan ini terlaksana karna adanya minat investor dalam berinvestasi.Dalam berinvestasi yang paling penting dilihat oleh investor adalah persepsinya terhadap perusahaan, dihubungkan dengan harga saham . Tingginya nilai perusahaan disebabkan oleh tingginya harga saham. Menurut Husnan (2013) nilai perusahaan adalah sebuah nilai yang dikeluarkan oleh calon pembeli jika suatu saat perusahaan akan dijual. Nilai perusahaan menciptakan kemakmuran pemegang saham secara maksimum apabila harga saham tersebut meningkat. Semakin banyak peningkatan harga saham sebuah perusahaan, sehingga maksimum pula kemakmuran pemegang saham. Kenaikan harga saham perusahaan dipasar modal disebabkan oleh peningkatan permintaan saham suatu perusahaan (Zumrotun, 2013), dari 6 daftar perusahaan Otomotif kenapa masih banyak Nilai Perusahaan Otomotif yang masih dihargai rendah yang menjadi pertayaan yang akan dicari tau penyebabnya dalam penelitian ini.

Pembahasan nilai perusahaan, mengingatkan akan kejadian tutupnya perusahaan PT.Ford Motor Indonesia (FMI) selaku agen Ford pada tgl 25 januari 2016, yang telah berpartisipasi dalam industri otomotif di Indonesia dari tahun 2002. PT.Ford Motor Indonesia (FMI) mengalami kerugian besar saat penjulan menurun sekitar $50 \%$ pada tahun 2015 , menurunnya penjualan disebabkan karna 
tingginya tarif pajak penjualan barang mewah (PPNBM) hingga 125\% membuat penjualan anjlok dan mengalami kerugian, selain itu jauhnya pabrikasi komponen Ford membuat pengguna mobil ford kewalahan dengan suku cadangnya, sulitnya meraih suku cadang membuat orang enggan untuk membeli mobil Ford.

Keluarnya Ford dari Dunia otomotif Indonesia memberikan dampak terhadap para pengguna mobil ford yang tambah sulit untuk melakukan servis dan suku cadang.Dengan hengkangnya ford dikarenakan oleh jauhnya pabrikasi komponen membuat perusahaan otomotif mempertahankan kelebihan mereka dalam hal penyediaan komponen lengkap untuk brand merk mereka.

Turunnya angka penjualan membuat saham Ford Motor Co yang listing di NYSE menurun sebesar 1,32\%. Naik turunnya harga saham sangat berpengaruh pada Perusahaan Otomotif yang mempengaruhi nilai suatu perusahaan.

Tujuan dari penelitian ini adalah untuk mengetahui dan menganalisa tentang bagaimana pengaruh struktur modal terhadap nilai perusahaan,pengaruh ukuran perusahaan terhadap nilai perusahaan dan pengaruh profitabilitas terhadap nilai perusahaan.Sujoko dan Soebiantoro (2007) dalam Sri Hermuningsih (2009) mengatakan bahwa nilai perusahaan merupakan presepsi investor terhadap tingkat keberhasil perusahaan yang terkait erat dengan harga saham yang tinggi membuat nilai perusahaan juga tinggi, dan meningkatkan keperayaan pasar tidak hanya terhadap kinerja perusahan saat ini namun juga pada prospek perusahaan dimasa yang akan datang.

Rumondor et al., 2015) mendefinisikan struktur modal adalah pembelanjaan permanen di dalam mencerminkan perimbangan antara hutang jangka panjang dan modal sendiri. Dengan demikian dapat disimpulkan bahwa struktur modal merupakan perbandingan antara sumber jangka panjang yang bersifat pinjaman dan modal sendiri.Wedari (2006) dalam ( ayu sri mahatma Dewi \& Wirajaya, 2013) menyebutkan bahwa ukuran perrusahaan adalah peningkatan dari kenyataan bahwa perusahaan besar akan memilki kapitalisasi pasar yang besar, nilai buku yang besar dan laba yang tinggi. Ferry dan Jones dalam (Rumondor et al., 2015) mengatakan ukuran perusahaan menggambarkan besar kecilnya suatu perusahaan yang ditunjukkan oleh total aktiva dan jumlah penjualan.

Profitabilitas suatu perusahaan diukur dengan kesuksesan perusahaan dan kemampuan menggunakan aktivanya secara produktif, dengan demikian profitabilitas suatu perusahaan dapat diketahui dengan membandingkan antara laba yang diperoleh dalam suatu periode dengan jumlah aktiva atau jumlah modal perusahaan tersebut. Brigham dkk (2009) dalam (Manoppo \& Arie, 2016)mendefinisikan Profitabilitas adalah hasil akhir dari sejmlah kebijakan dan keputusan manajemen perusahaan.

\section{Pengaruh Struktur Modal terhadap nilai perusahaan}

Struktur modal adalah pembelanjaan permanen di dalam mencerminkan perimbangan antara hutang jangka panjang dan modal sendiri menurut Riyanto (2008:22) dalam (Manoppo \& Arie, 2016) .Perusahaan yang menggunakan hutang dalam operasinya akan mendapat penghematan pajak, karena pajak dihitung dari laba operasi setelah dikurangi bunga hutang, sehingga laba bersih yang menjadi hak pemegang saham akan menjadi lebih besar dibandingkan dengan perusahaan yang tidak menggunakan hutang (Meythi, 2012) dalam (Syahadatina, 2015). Dengan demikian nilai perusahaan pun juga menjadi lebih 
besar. Ini berarti semakin besar struktur modalnya maka nilai perusahaan juga akan semakin meningkat. Jadi dapat diketahui bahwa struktur modal berpengaruh terhadap nilai perusahaan.Penelitian dari (Moniaga, 2011) yang memeliti tentang Struktur Modal,Profitabiltas, dan Struktur Biaya terhadap Nilai Perusahan Industri Keramik ,Porcelen dan Kaca priode 2007-2011,menyatakan bahwa Struktur Modal berpengaruh signifikan terhadap Nilai Perusahaan, demikian juga hasil yng sama dinyatakan dalam penelitian (Manoppo \& Arie, 2016) dengan judul Pengaruh Struktur Modal,Ukuran Perusahaan dan Profitabiltas terhadap Nilai Perusahan Otomotif yang terdaftar di Bursa Efek Indnesia perode 2011-2014 dimana hasil penelitiannya menyatakan bahwa Struktur Modal berpengaruh positif signifikan terhadap Nilai Perusahaan. Penelitian dengan hasil yang sama juga dilakukan oleh ( ayu sri mahatma Dewi \& Wirajaya, 2013) yang menyatakan Struktur Modal berpengaruh signifikan terhadap Nilai Perusahaan dengan judul penelitian Pengaruh Struktur Modal, Profitabiltas, dan Ukuran Perusahaan terhadap Nilai Perusahaan Industri Manufaktur yang terdaftar di Bursa Efek Indnesia 2009-2011. Berdasakan peneltian terdahulu maka disimpulkan Hipotesis bahwa diduga Struktur Modal berpengaruh positif dan signifikan terhadap nilai perusahaan.

\section{Pengaruh Ukuran Perusahaan terhadap nilai perusahaan}

Ukuran perusahaan adalah besar kecilnya perusahaan dapat diukur dengan total aktiva/ besar harta perusahaan dengan menggunakan perhitungan nilai logaritma total aktiva Menurut Hartono (2000:254) dalam (Noor, 2014).Ukuran perusahaan dianggap mampu untuk memengaruhi nilai dari suatu perusahaan (Martini dkk, 2014) dalam (Igusti Ngurah Agung Dwi Pramana \& Mustanda, 2016) . Semakin besar ukuran atau skala perusahaan maka akan semakin mudah pula perusahaan untuk dipercaya oleh kreditur dalam memperoleh sumber dana yang besar baik bersifat internal maupun eksternal. Sumber dana tersebut dapat digunakan oleh perusahaan untuk lebih meningkatkan keuntungan perusahaan melalui ekspansi dan effisiensi (Maspupah, 2014). Selain itu dengan semakin besar ukuran perusahaan, maka ada kecenderungan lebih banyak investor yang menaruh perhatian pada perusahaan tersebut. Hal ini disebabkan karena perusahaan yang besar cenderung memiliki kondisi yang lebih stabil dari tahun ke tahun utamanya dalam return saham kepada investor. Peningkatan permintaan akan saham suatu perusahaan menjadi penyebab atas naiknya harga saham perusahaan di pasar modal yang berujung pada kenaikan nilai perusahaan (Zumrotun, 2013). Hal ini didukung oleh penelitian ( ayu sri mahatma Dewi \& Wirajaya, 2013) meneliti tentang Pengaruh Struktur Modal, Profitabiltas, dan Ukuran Perusahaan terhadap Nilai Perusahaan Industri Manufaktur yang terdaftar di Bursa Efek Indnesia 2009-2011 dimana hasil penelitiannya menyatakan bahwa Ukuran Perusahaan berpengaruh positif dan signifikan terhadap Nilai Perusahaan. Hasil yang sama juga dinyatakan dalam penelitian yang dilakukan oleh (Prasetia, Tommy, \& Saerang, 2014) yang meneliti tentang Struktur Modal,Ukuran Perusahan dan Risiko Perusahaan teradap Nilai Perusahaan Otomotif di BEI dimana hasil penelitiannya menyatakan bahwa Ukuran Perusahaan berpengaruh positif dan signifikan terhadap Nilai Perusahaan. Hasil berbeda dinyatakan oleh penelitian yang dilakukan (Rumondor et al., 2015) yang meneliti tentang Struktur Modal,Ukuran Perusahan dan Risiko Perusahaan teradap Nilai Perusahaan pada Sub Sektor Plastik dan Pengemasan di BEI dimana hasil 
penelitiannya menyatakan bahwa Ukuran Perusahaan berpengaruh negatif tidak signifikan terhadap Nilai Perusahaan.Berdasakan peneltian terdahulu maka disimpulkan Hipotesis bahwa diduga Ukuran Perusahaan berpengaruh postif dan signifikan terhadaap Nilai Perusahaan

\section{Pengaruh Profitabilitas terhadap Nilai Perusahaan}

Profitabilitas adalah "kemampuan perusahaan memperoleh laba melalui operasional usahanya dengan menggunakan dana aset yang dimiliki oleh perusahaan" menurut Kusuma (2013) (dalam Rahmawati et al., 2013).Apabila kemampuan perusahaan untuk menghasilkan laba meningkat, maka harga saham juga akan meningkat (Husnan, 2001:317) (dalam (Igusti Ngurah Agung Dwi Pramana \& Mustanda, 2016). Profitabilitas yang tinggi mencerminkan kemampuan perusahaan dalam menghasilkan keuntungan yang tinggi bagi pemegang saham. Semakin besar keuntungan yang diperoleh semakin besar pula kemampuan perusahaan untuk membayarkan devidennya, dan hal ini berdampak pada kenaikan nilai perusahaan. Dengan rasio profitabilitas yang tinggi yang dimiliki sebuah perusahaan akan menarik minat investor untuk menanamkan modalnya diperusahaan (Dewi dan Wirajaya, 2013). Martalina (2011) juga menyatakan bahwa dengan tingginya tingkat laba yang dihasilkan, berarti prospek perusahaan untuk menjalankan operasinya di masa depan juga tinggi sehingga nilai perusahaan yang tercermin dari harga saham perusahaan akan meningkat pula.Penelitian yang dilakukan oleh (Igusti Ngurah Agung Dwi Pramana \& Mustanda, 2016) yang berjudul Pengaruh profitabilitas dan size terhadap nilai perusahaan dengan csr sebagai variabel pemoderasi menyatakan bahwa Profitabilitas berpengaruh signifikan terhadaap Nilai Perusahaan.

Penelitian lain juga menyatakan Profitabilitas berpengaruh positif signifikan terhadaap Nilai Perusahaan dengan judul Pengaruh struktur modal, profitabilitas dan ukuran perusahaan pada nilai perusahaan manufktur yang terdaftar di BEI than 2009 - 2011, oleh ( ayu sri mahatma Dewi \& Wirajaya, 2013). Sedangkan penelitian (Manoppo \& Arie, 2016) menyatakan hasil Profitabilitas berpengaruh negatife tidak signifikan terhadaap Nilai Perusahaan pada penelitian Pengaruh Struktur modal, ukuran perusahaan dan profitabilitas terhadap nilai perusahaan otomotif yang terdaftar di bursa efek indonesia periode 2011 - 2014. Berdasakan peneltian terdahulu maka disimpulkan Hipotesis bahwa diduga Profitabilitas berpengaruh positing signifikan terhadaap Nilai Perusahaan.

\section{Kerangka Konseptual}

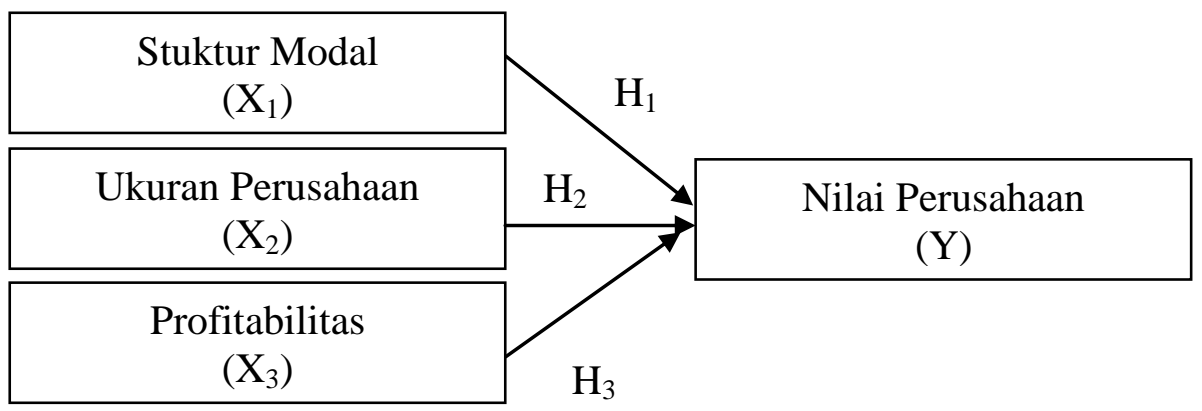

Gambar 1

Kerangka konseptual 


\section{METODE PENELITIAN}

Jenis penelitian yang digunakan adalah penelitian kuantitatif. Penelitian ini bertujuan untuk menjelaskan "Pengarauh Struktur Modal, Ukuran Perusahaan dan Profibilitas terhadap Nilai Perusahaan Otomotif yang terdaftar di Bursa Efek Indonesia Periode 2012-2016 ".Jumlah populasi yang digunakan adalah 13 perusahaan otomotif yang terdaftar di Bursa Efek Indonesia.Sampel yang diperoleh adalah sebanyak 6 perusahaan.Jenis penelitian ini adalah penelitian kuantitatif .Sumber data dalam proposal ini adalah data sekunder . Data yang dipakai diproposal ini didapat dari situs resmi Bursa Efek Indonesia dari tahun 2012 -2016.Data mengenai laporan keuangan ini didapat dari situs resmi Bursa Efek Indonesia (www.idx.co.id).Teknik pengumpulan data yang dipakai dipenelitian ini ialah teknik dokumentasi , dengan mengumpulkan data laporan keuangan yang di sajikan melalui situs Bursa Efek Indonesia (www.idx.co.id).

Definisi Operasional Variabel

Tabel 1

Defenisi Operasional Variabel

\begin{tabular}{|c|c|c|c|c|}
\hline No & Variabel & Definisi & Pengukuran & Sumber \\
\hline 1 & $\begin{array}{l}\text { Nilai } \\
\text { Perusahaan }\end{array}$ & $\begin{array}{l}\text { Menurut Sujoko dan } \\
\text { Soebiantoro (2007, } \\
58) \text { dalam (Chaidir, } \\
\text { 2014) hubungan } \\
\text { keberhasilan } \\
\text { perusahaan dengan } \\
\text { harga sahamyang } \\
\text { memperngruhi } \\
\text { pemikiran investor } \\
\text { adalah gambaran } \\
\text { "Nilai perusahaan }\end{array}$ & $\begin{array}{l}\text { Price Book Vaue } \\
(\mathrm{PBV})= \\
\text { Harga perlembar saham } \\
\text { Nilai Buku Saham }\end{array}$ & $\begin{array}{l}\text { (Weston } \\
\text { dan } \\
\text { Copelan } \\
\text { 2004) }\end{array}$ \\
\hline 2 & $\begin{array}{l}\text { Struktur } \\
\text { Modal }\end{array}$ & \begin{tabular}{lr} 
Menurut & Sjahrial \\
$(2014$, 250) & dalam \\
(Chaidir, & 2014) \\
"Struktur & modal \\
merupakan & \\
perimbangan & dari \\
pemakaian & utang \\
jangka rande & pendek \\
dimana modal \\
sendiri berasal dari \\
saham preferen dan \\
\multicolumn{2}{l}{ saham biasa. }
\end{tabular} & $\begin{array}{l}\text { Debt to Equity Ratio } \\
(\text { DER) }= \\
\frac{\text { Total Debt }}{\text { Total Equity }} \times 100 \%\end{array}$ & $\begin{array}{l}\text { (Sutrisno } \\
2012 \text { ) }\end{array}$ \\
\hline 3 & $\begin{array}{l}\text { Ukuran } \\
\text { Perusahaan }\end{array}$ & $\begin{array}{lr}\text { Ferry dan } & \text { Jones } \\
\text { (Sujianto, 2001:37), } \\
\text { mengatakan } & \text { ukuran } \\
\text { perusahaan } & \\
\text { merupakan } & \text { suatu } \\
\text { gambaran } & \text { besar } \\
\text { kecilnya } & \text { suatu } \\
\text { perusahaan yang } \\
\text { dilihat dari jumlah } \\
\text { aktiva dan } \\
\text { penjualan }\end{array}$ & Size $=$ Ln (Total asset) & $\begin{array}{l}\text { (Asnawi \& } \\
\text { Wijaya } \\
\text { 2005) }\end{array}$ \\
\hline
\end{tabular}




\begin{tabular}{|c|c|c|c|c|}
\hline 4 & $\begin{array}{l}\text { Profitabilita } \\
\mathrm{s}\end{array}$ & $\begin{array}{l}\text { Profitabilitas } \\
\text { (profitability) } \\
\text { menurut Kusuma } \\
(2013) \text { dalam } \\
\text { (Rahmawati et al., } \\
\text { 2013) ialah seberapa } \\
\text { besar perusahaan } \\
\text { mendapatkan laba } \\
\text { lewat operasional } \\
\text { usaha dengan } \\
\text { memanfaatkan dana } \\
\text { asset perusahaan }\end{array}$ & $\begin{array}{l}\text { Return On Asset (ROA) } \\
=\frac{\text { laba bersih }}{\text { total aktiva }} \times 100 \%\end{array}$ & $\begin{array}{l}\text { (Harahap } \\
\text { 2002) dan } \\
\text { (Zulfa Eka } \\
\text { Sari 2013) }\end{array}$ \\
\hline
\end{tabular}

\section{Teknik Analisis Data}

Metode analisis data yang dipakai pada penelitian ini ialah teknik analisis regresi linear berganda. Analisis ini dipakai mengetahui pengaruh antara struktur modal,ukuran perusahaan dan profitabilitas terhadap nilai perusahaan Ototmotif di BEI.

\section{Analiisis Statistik Deskriptif}

Uji statistik deskriptif berkenaan dengan bagaimana data dapat digambarkan /dideskripsikan, baik secara numeric misalya mencari rata - rata, standar deviasi atau secara grafis berupa tabel atau grafik.Untuk mendapatkan gambaran yang menjadi acuan untuk mengetahui karaktristik data yang diperoleh.

\section{Uji Asumsi Klasik}

Uji asumsi klasik digunakan untuk mendapatkan penduga koefisien regresi yang mempunyai error terkecil atau bentuk regresi yang didapatknn adalah bersifat BLUE (Best Linier Unbiased Estimate) atau bersifat linier , tak berbias dan varian minimum. Adapun uji asumsi klasik ialah :

\section{Uji Normalitas Data}

Menurut Ghozali (2011) uji normalitas ialah uji yang dipakai untuk mengetahui distribusi data mengikuti pola distribusi norml atau tidak, atau melakukan uji apakah model regresi, variabel dependen dan variabel independen atau keduanya memiliki distibusi normal atau tidak. Data terdistribsi normal jika Probabilitas > 0.05 maka distribusi normal, dan sebaliknya bila probabilitas < 0.05 maka distribusi tidaknormal.

\section{Uji Multikolinearitas}

Uji multikolinearitas yaitu hubungan sesama variable bebas. Multikolinearitas ialah kondisi dimana variable-variabel bebas pada persamaan regresi memiliki kolerasi (hubungan) yang kuat .

Suatu cara yang bias dilakukan untuk melihat ada tidaknya multikolinearitas pada model rgresi adalah dengan melihat nilai tolerance dan VIF (Variance Inflation Factor), yaitu ; Jika nilai tolerance $>0.10$ dan VIF $<10$, maka bisa disimpulkan bahwa tidak terjadi multikolinearitas dan sebaliknya jika nilai tolerance $<0.10$ dan VIF $>10$, maka bias disimpukan bahwa terjadi multikolinearitas.

\section{Uji Heteroskedastisitas}

Uji heteroskedastisitas digunakan untuk menlihat adakah dmodel regresi terdapat perbedaan varians dari residual suatu pengamatan ke pengamatan yang 
lain (Ghozali, 2005). Caranya dengan melakukan uji glejser dengan ketentuan jika nilai signifikan $>0,05$ maka tidak terjadi heteroskedastisitas dan jika nilai signifikan $<0,05$ maka terjadi heteroskedastisitas.

\section{Uji Autokorelasi}

Uji autokorelasi dipakai untuk mengetahui ada tidaknya autokorelasi, autokorelasi adalah korelasi yang terjadi diantara anggota-anggota dari serangkaian pengamatan yang sistematis pada data time series. Model penelitian terbaik ilah tidak terjadi autokorelasi. Uji yang diapakai untuk melihat adanya gejala autokorelasi adalah Durbin-Waston Statistic Test. Jika Durbin-Wastonnya antara -2 sampai 2 berarti tidak terjadi autokorelasi (Gujarti, 2003).

\section{Analisis Regresi Berganda}

teknik analisis regresi linier berganda untuk mengolah dan membahas data yang telah didapatkan dan untuk melakuakn uji hipotesis yang diajukan.

Model persamaan regresi untuk menguji hipotesis dengan formula adalah:

$$
\mathrm{Y}=\mathrm{a}+\mathrm{LNb}_{1} \mathrm{X}_{1}+\mathrm{LN} \mathrm{b}_{2} \mathrm{X}_{2}+\mathrm{LN} \mathrm{b}_{3} \mathrm{X}_{3}+\mathrm{e}_{1}
$$

\section{Dimana :}

$\mathrm{Y} \quad=$ Nilai perusahaan

a $\quad=$ Konstanta

LN = Logaritma Natural

$\mathrm{b}_{1} \quad=$ Koefesien Regresi Struktur Modal

$\mathrm{X}_{1} \quad=$ Tingkat Struktur Modal

$\mathrm{b}_{2} \quad=$ Koefesien Regresi Ukuran Perusahaan

$\mathrm{X}_{2}=$ Ukuran Perusahaan

$\mathrm{b}_{3} \quad=$ Koefesien Regresi Profitabilitas

$\mathrm{X}_{3} \quad=$ Profitabilitas

$\mathrm{e}_{1} \quad=$ error

\section{Uji Hipotesis}

Setelah dinyatakan bebas dari penyimpangan asumsi klasik selanjutnya adalah pengujian secara statistik untuk melihat apakah semua variabel independennya memang secara bersama-sama atau parsial mempunyai pengaruh terhadap variabel dependennya. Uji statistik adalah menguji apakah hasil yang dicapai sudah sesuai dengan metode-metode statistik yang ada, meliputi:

\section{Uji F (simultan)}

Uji F dipakai untuk menguji pengaruh variabel independen yaitu Struktur Modal,Ukuran Perusahaan Dan Profitabilitas secara bersama-sama berpengaruh terhadap variabel dependen yaitu Nilai Perusahaan dari suatu persaman regresi yang didasarkan pada nilai probabilitas $\mathrm{a}=0,05$ dengan kriteria pengujian sebagai berikut :

Jika probabilitas $>0,05$ maka $\mathrm{H}_{1}$ ditolak, $\mathrm{H}_{0}$ diterima.

Jika probabilitas $<0,05$ maka $\mathrm{H}_{1}$ diterima, $\mathrm{H}_{0}$ ditolak.

\section{Uji t (Parsial)}

Uji t dipakai untuk menguji pengaruh variabel independen secara parsial terhadap variabel dependen, yaitu pengaruh dari variabel independen (Struktur Modal,Ukuran Perusahaan Dan Profitabilitas) terhadap variabel dependen (Nilai Perusahaan) yang memiliki dasar penilaian probabilitas $\mathrm{a}=0,05$ dengan kriteria pengujian sebagai berikut : 
Jika probabilitas $>0,05$ maka $\mathrm{H}_{1}$ ditolak, $\mathrm{H}_{0}$ diterima.

Jika probabilitas $<0,05$ maka $\mathrm{H}_{1}$ diterima, $\mathrm{H}_{0}$ ditolak.

\section{Koefisien Determinasi $\left(\mathbf{R}^{2}\right)$}

Koefisien determinasi dipakai untuk melihat hubungan antara Struktur Modal,Ukuran Perusahaan Dan Profitabilitas terhadap Nilai Perusahaan Koefisien determinasi berkisar dari nol sampai dengan satu $\left(0 \leq \mathrm{R}^{2} \leq 1\right)$. Hal ini berarti bila $\mathrm{R}^{2}=0$ memperlihatkan bahwa tidak adanya pengaruh antara variabel dependen, apabila $\mathrm{R}^{2}$ semakin besar terhadap variabel dependen dan bila $\mathrm{R}^{2}$ semakin kecil mendekati 0 maka dapat diartikan bahwa semakin kecilnya pengaruh variabel independen terhadap variabel dependen.

\section{HASIL DAN PEMBAHASAN \\ Statistik Deskriptif}

\section{Tabel 2}

Deskriptive Statistics

\begin{tabular}{llllll}
\hline & $\mathrm{N}$ & Minimum & Maximum & Mean & Std.Deviation \\
\hline PBV & 30 & .12 & 19.03 & 2.6117 & 3.396649 \\
DER & 30 & .01 & 3.95 & 0.8027 & 0.73015 \\
SIZE & 30 & 12.11 & 28.57 & 19.182 & 5.65920 \\
ROA & 30 & .10 & 24.00 & 8.2747 & 6.45445 \\
Valid N (listwise) & 30 & & & &
\end{tabular}

Sumber Data : Hasil Olahan SPSS 16

Berdasarkan hasil uji statistik deskriptif menyatakan nilai minimum pada variabel PBV (Nilai Perusahaan) sebesar 0,12 tahun 2015 yang diperoleh Perusahaan Indospring Tbk (INDS ), dan nilai maksimum sebesar 19.03 tahun 2015 yang diperoleh Perusahaan Selamat Sempurna Tbk.(SMSM) dengan niali rata - rata 2,6117 dan standar deviasi sebesar 3,39649. Variabel DER (Stuktur Modal) menunjukkan angka minimum sebesar 0,01 tahun 2016 yang dimiliki oleh Perusahaan Goodyear Indonesia Tbk.(GDYR), nilai maksimum dengan angka 3,95 tahun 2013 adalah angka DER dari Perusahaan Indospring Tbk. (INDS) dimana nilai rata - rata 0,8027 dan standar deviasi sebesar 0,73015.Nilai minimum variabel SIZE (Nilai Perusahaan) menunjukkan angka 12,11 tahun 2012 yang diperoleh dari perusahaan Astra Internasional Tbk. (ASII) dan nilai maksimum 28,57 tahun 2015 adalah angka size dari perushaan Indospring Tbk.(INDS) dimana nilai rata - rata 19,1823 dengan standar deviasi 5,65920, kemudian angka minimum untuk variabel ROA 0,10 tahun 2015 yang diperoleh Perusahaan Indospring Tbk (INDS ) dengan nilai maksimum 24,00 tahun 2014 oleh Perusahaan Selamat Sempurna Tbk.(SMSM) dengan nilai rata - rata 8,2747 dimana standar deviasinya 6,45445.

\section{Uji Asumsi Klasik}

\section{Tabel 3}

Uji Normalitas Data

Kolmogorov-Smirnov Z 1,037

Asymp.Sig(2 tailed) 0.232

Sumber Data : Hasil Olahan SPSS 16

Dari table diatas dilihat bahwa nilai sig 0,232 yang berarti bahwa nilai signifikan > 0.05 menyatakan bahwa data terdistribusi normal. 
Uji Multikolinearitas

Tabel 4

\begin{tabular}{llll}
\hline \multicolumn{3}{l}{ Collinearity Statistics } \\
\hline & \multicolumn{2}{l}{ Tolerance } & Keterangan \\
\hline Variabel & $\mathrm{e}$ & VIF & \\
DER & .929 & 1.077 & Tidak Terjadi Multikolinearitas \\
SIZE & .887 & 1.127 & Tidak Terjadi Multikolinearitas \\
ROA & .828 & 1.208 & Tidak Terjadi Multikolinearitas \\
\hline
\end{tabular}

Sumber Data : Hasil Olah SPSS 16

Berdasarkan table variabel DER (Struktur Modal) memiliki nilai tolerance sebesar 0.929 dan nilai VIF sebesar 1.077 , variabel Size (Ukuran Perusahaan) memiiliki nilai tolerance sebesar 0,887 dan nilai VIF sebesar 1,127 dan variabel ROA (Profitabilitas ) dengan nilai tolerance 0,828 dan nilai VIF 1,208 yang berarti bahwa ketiga variabel memiliki nilai tolerance $>0.1$ dan nilai VIF $<10$ yang menunjukkan bahwa tidak terjadi korelasi (hubungan) antara variabel independen atau variabel bebas.

\section{Uji Heteroskedastisitas}

Tabel 5

\begin{tabular}{lll}
\hline Variabel & Sig. & Keterangan \\
\hline DER & .277 & Tidak Terjadi Heteroskedastisitas \\
SIZE & .074 & Tidak Terjadi Heteroskedastisitas \\
ROA & .699 & Tidak Terjadi Heteroskedastisitas \\
\hline
\end{tabular}

Sumber Data : Hasil Olahan SPSS 16

Pada table dapat dilhat bahwa variabel DER (Struktur Modal ) memiliki nilai signifikan 0,277, variabel SIZE (Ukuran Perusahaan) memiliki nilai signifikan 0,074 dan Variabel ROA (Profitabilitas) dengan nilai signifikan 0,699 yang menunjukkan bahwa semua variabel memiliki nilai signifikan $>0.05$ yang artinya tidak terjadi heteroskedastisitas.

\section{Uji Autokorelasi}

Tabel 6

\begin{tabular}{ll}
\hline Model & Durbin-Watson \\
1 & 2,000 \\
\hline
\end{tabular}

Sumber Data : Hasil Olahan SPSS 16

Pada tabel dapat dlihat bahwa hasil Uji Autokorelasi memiliki nilai Durbin Watson sebesar 2 dimana $<-2$ dan $>2$ yang yang artinya data yang digunakan dalam penelitian ini bebas dari Autokorelasi.

\section{Uji Analisis Regresi Berganda}

\section{Tabel 7}

\begin{tabular}{ll}
\hline Variabel & Koefisien Regresi \\
\hline (Constatnt) & 0.773 \\
DER & 0.094 \\
SIZE & -0.471 \\
ROA & 0.671 \\
\hline
\end{tabular}

\section{Sumber Data : Hasil Olahan SPSS 1}

Dari table ditemukan suatu persamaan regresi untuk mengetahui pengaruh struktur modal, ukuran perushaan dan profitabilitas tehadap nilai perusahaan sebagai berikut :

$$
Y=0,773+0,094 X_{1}-0,471 X_{2}+0,671 X_{3}+e
$$


Keterangan :

$$
\begin{aligned}
& \mathrm{Y}=\text { Nilai Perusahaan (PBV) } \\
& \mathrm{a}=\text { Konstanta } \\
& \mathrm{X}_{1}=\text { StrukturModal (DER) } \\
& \mathrm{X}_{2}=\text { Ukuran Perusahaan (SIZE) } \\
& \mathrm{X}_{3}=\text { Profitabilitas (ROA) } \\
& \mathrm{e}=\text { error }
\end{aligned}
$$

Tanda pada koefisien regresi mencerminkan hubungan antara variabel independen (sturktur modal,ukuran perusahaan dan profitabilitas) dengan variabel dependen (nilai perusahaan) pada perusahaan otomotif yang terdaftar di Bursa Efek Indonesia .Tanda (+) menandakan adanya hubungan positif atau searah antara variabel independen dan variabel dependen. Sedangkan tanda (-) menandakan tidak terdapat hubungan antara variabel independen dan variabel variabel dependen.

Dari persamaan diatas dapat disimpulkan bahwa Nilai Konstanta pada persamaan regresi menunjukkan angka 0,773 yang artinya bahwa jika variabel independen lainnya bernilai nol, maka variabel nilai perusahaan mengalami kenaikan sebesar 0,773 satuan.Koefisien regresi variabel struktur modal (X1) sebesar 0,094 menyatakan jika variabel struktur modal meningkat satu satuan maka variabel nilai perusahaan akan mengalami kenaikan sebesar 0,094 satuan dengan ketentuan variabel lain konstan.Koefisien regresi variabel ukuran perusahaan (X2) sebesar -0,471 menyatakan jika variabel ukuran perusahaan meningkat satu satuan maka variabel nilai perusahaan akan mengalami penurunan sebesar 0,471 satuan dengan ketentuan variabel lain konstan.Koefisien regresi variabel profitabilitas (X3) sebesar 0,671 menyatakn jika variabel profitabilitas (X3) naikt satu satuan maka variabel nilai perusahaan akan mengalami kenaiakn sebesar 0,671 satuan dengan ketentuan variabel lain konstan.

\section{Uji Hipotesis \\ Uji F (Simultan)}

\section{Tabel 8}

\begin{tabular}{lll}
\hline Keterangan & $\mathrm{F}_{\text {hitung }}$ & Keterangan \\
\hline Regression & 20.129 & 0.000 \\
\hline Sumber Data $:$ Hasil Olahan SPSS 16
\end{tabular}

Dari table bisa disimpulkan jika variabel independen yaitu struktur modal, ukuran perusahaan dan profitabilitas secara bersama - sama berpengaruh signifikan terhadap nilai perusahaan, yang ditunjukkan dengan $\mathrm{F}$ hitung sebesar 20,129 denga nilai sig. 0,000 $<0.05$ maka Ho diterima .

\section{Uji t (Parsial)}

Tabel 9

\begin{tabular}{llll}
\hline Keterangan & $\mathrm{T}_{\text {hitung }}$ & $\mathrm{T}_{\text {tabel }}$ & $\mathrm{Sig}$ \\
\hline DER & 0.865 & 1.70113 & 0.395 \\
SIZE & -1.217 & 1.70113 & 0.234 \\
ROA & 6.342 & 1.70113 & 00.000 \\
\hline
\end{tabular}

Sumber Data : Hasil Olahan SPSS 16

Dari data table dilihat bahwa,Variabel struktur modal (DER) memiliki t hitung sebesar $0,865<$ dari t tabel sebesar 1,70113 dengan tingkat sig. 0.395 > 0.05 yang menyatakan $\mathrm{H}_{0}$ diterima dan $\mathrm{H}_{1}$ ditolak sehingga bisa disimpulkan 
bahwa variabel struktur modal tidak berpengaruh terhadap nilai perusahaan.variabel ukuran perusahaan (SIZE) memiliki t hitung sebesar -1,217 < dari $\mathrm{t}$ tabel sebesar 1,70113 dengan tingkat sig. $0.234>0.05$ yang menyatakan $\mathrm{H}_{0}$ diterima dan $\mathrm{H}_{1}$ ditolak sehingga bisa disimpulkan bahwa variabel ukuran perusahaan tidak berpengaruh terhadap nilai perusahaan.variabel profitabilitas (ROA) memiliki t hitung sebesar 6,342 > dari t tabel sebesar 1,70113 dengan tingkat sig. $0.000>0.05$ yang menyatakan $\mathrm{H}_{0}$ ditolak dan $\mathrm{H}_{1}$ diterima sehingga bias disimpulkan bahwa variabel profitabilitas berpengaruh positif dan sig. terhadap nilai perusahaan.

\section{Koefisien Determinasi $\left(\mathbf{R}^{2}\right)$}

Nilai $\mathbf{R}^{2}$ atau koefisien determinasi digunakan untuk mengukur seberapa jauh model dalam menerangkan variasi variabel dependen.

Tabel 10

\begin{tabular}{ll}
\hline Model $\quad$ Adjusted R Square \\
\hline Sumber Data $:$ Hasil Olahan SPSS 16
\end{tabular}

Dari table dapat dilihat bahwa nilai $\mathrm{r}^{2}$ adalah 0,664 atau $66,4 \%$ dimana persentase sumbangan variabel independen yaitu Sturktur modal, ukuran perusahaan, dan profitabilitas terhadap variabel dependen yaiut nilai perusahaan sebesar $66,4 \%$, dimana sisanya 33,6\% dipengaruhi oleh variabel lain yang tidak dimasukkan dalam model penelitian ini seperti kebijakan pendanaan,deviden,keputusan investasi, dan pertumbuhan perusahan.

\section{PEMBAHASAN}

\section{Pengaruh Struktur Modal terhadap Nilai Perusahaan}

Hasil hipotesis menunjukkan bahwa struktur modal tidak berpengaruh signifikan terhadap nilai perusahaan otomotif yang terdaftar di Bursa Efek Indonesia periode tahun 2012 - 2016, yang ditunjukkan oleh t hitung sebesar $0,865<$ dari t tabel sebesar 1,70113 dengan tingkat sig. $0.395>0.05$. Pada tahun 1950-an Modigliani dan Miller menentang pandangan tradisional mengenai struktur modal. Pendapat mereka menyatakan bahwa struktur modal tidak memiliki pengaruh terhadap nilai perusahaan. Mereka memperkenalkan model dari teori struktur modal secara matematis dan scientific atas dasar penelitian yang dilakukan secara terus menerus yaitu; tidak ada pajak, investor dapat meminjam pada tingkat yang sama dengan perusahaan, informasi selalu tersedia bagi semua investor dan dapat diperoleh tanpa adanya biaya, serta EBIT tidak memiliki pengaruh terhadap penggunan hutang.Artinya nilai perusahaan menurun jika hutang yang digunakan perusahaan semakin besar dikarenakan modal terbesar diperoleh dari pendanaan ekternal bukan dari internal perushaan, sehingga kemampuan perusahaan dalam menghasilkan laba sangat rendah,kerugian atau keuntungan pendanaan ini dipengaruhi oleh kondisi bisnis pada priode tersebut,sehingga tidak memperngaruhi nilai perusahaan sama sekali.Hasil ini juga sesuai dengan penelitian yang dilakukan oleh (Antari \& Dana, 2010) yang berjudul Pengaruh struktur modal, kepemilikan manajerial, dan kinerja keuangan terhadap nilai perusahaan yang menyatakan bahwa Struktur Modal tidak berpengaruh signifikan terhadaap Nilai Perusahaan. Dan hasil yang sama juga dinyatakan dalam penelitian yang dilakukan oleh (Pasaribu, Yuniyanti, Topowijono, \& Sulasmiyati, 2016) yang berjudul Pengaruh struktur modal, 
struktur kepemilikan dan profitabilitas terhadap nilai perusahaan pada perusahaan sektor industri dasar dan kimia yang terdaftar di bei tahun 2011-2014.

\section{Pengaruh Ukuran Perusahaan terhadap Nilai Perusahaan}

Hasil hipotesis menunjukkan bahwa ukuran perusahaan tidak berpengaruh signifikan terhadap nilai perusahaan otomotif yang terdaftar di Bursa Efek Indonesia periode tahun 2012 - 2016, yang ditunjukkan oleh t hitung sebesar $1,217<$ dari t tabel sebesar 1,70113 dengan tingkat sig. $0.234>0.05$. Ukuran perusahaan umumnya berpengaruh pada penilaian investor dalam membuat keputusan investasi,caranya diukur dengan mengukur besarnya total asset yang dimiliki karena nilai total asset biasanya lebih besar dibandingkan variabel keuangan lainnya. Perusahaan besar memiliki tingkat kesenjangan informasi yang rendah dibandingkan dengan perusahaan yang lebih kecil, sehingga mendapatkan perolehan biaya ekuitas yang rendah. Tapi skala perusahaan besar mendapatkan akses lebih mudah untuk meraih sumber pendanaan Menurut Asymmetric information Theory. Pendanaan dari total asset dapat digunakan untuk opersional perusahaan,jika total asset berperan besar maka perusahaan akan dengan mudah mendapatkan simpati di pasar modal, jadi tinggi rendahnya ukuran perusahaan tidak akan berpengaruh terhadap nilai perusahaan. Penelitian ini sesuai dengan (Rumondor et al., 2015) yang melakukan penelitian tentang Struktur Modal,Ukuran Perusahan dan Risiko Perusahaan teradap Nilai Perusahaan pada Sub Sektor Plastik dan Pengemasan di BEI dimana hasil penelitiannya menyatakan bahwa Ukuran Perusahaan berpengaruh negatif tidak signifikan terhadap Nilai Perusahaan. (Setiadewi \& Purbawangsa, 2015) menyatakan hasil yang sama dengan judul penelitian Pengaruh Ukuran Perusahaan dan leverage terhadap Profitabilitas dan Nilai Perusahaan yang menyatakan hal sama bahwa Ukuran Perusahaan tidak berpengaruh terhadap Nilai Perusahan.

\section{Pengaruh Profitabilitas terhadap Nilai Perusahaan}

Hasil hipotesis menunjukkan bahwa profitabilatas berpengaruh positif dan signifikan terhadap nilai perusahaan pada perusahaan otomotif yang terdaftar di Bursa Efek Indonesia periode tahun 2012 - 2016 dengan t hitung sebesar 6,342 > dari t tabel sebesar 1,70113 dengan tingkat sig. $0.000>0.05$. Pecking Order Theory menyatakan perusahaan dengan tingkat keuntungan yang besar memiliki sumber pendanaan internal yang lebih besar mendorong perusahaan menggunakan dana tersebut utuk memenuhi kebutuhan guna melakukan pembiayaan investasi perusahaan sehingga tingkat penggunaan hutangnya atau pendanaan eksternal relatif kecil dan dapat memperkecil resiko kebangkrutan da biaya hutang yang tinggi. resiko kebangkrutan yang kecil membuat investor yakin akan saham yang mereka tanam di perusahaan tersebut, sehingga membuat nilai perusahaan meningkat di mata investor.Penelitian ini sesuai dengan penelitian yang berjudul Pengaruh struktur modal, profitabilitas dan ukuran perusahaan pada nilai perusahaan manufktur yang terdaftar di BEI tahun 2009 - 2011, oleh ( ayu sri mahatma Dewi \& Wirajaya, 2013) yang membuktikan bahwa semakin tinggi profitabilitas maka nilai perusahaan tinggi, dan semakin rendah profitabilitas maka nilai perusahaan rendah. (Hamidy, Wiksuana, Gede, \& Artini, 2015) juga menyatakan hal yang sama dalam penelitiannya Pengaruh Struktur Modal terhadapa Nilai Perusahaan dengan Profitabilitas sebagai Variabel Intervening pada Perusahaan Properti dan Real Estate di BEI. 


\section{KESIMPULAN}

Kesimpulan dari penelitian ini adalah Struktur Modal memiliki pengaruh positif tidak signifikan terhadap Nilai Perusahaan Otomotif yang terdaftar di Bursa Efek Indonesia (BEI) periode 2012 -2016.Ukuran Perusahaan memiliki pengaruh negative tidak signifikan terhadap Nilai Perusahaan Otomotif yang terdaftar di Bursa Efek Indonesia (BEI) periode 2012 -2016.Profitabilitas memiliki pengaruh positif dan signifikan terhadap Nilai Perusahaan Otomotif yang terdaftar di Bursa Efek Indonesia (BEI) periode 2012 -2016.

\section{UCAPAN TERIMAKASIH}

Ucapan terimakasih untuk Bapak Febryandhie Ananda, S.E, M.Si selaku Ketua STIE “KBP" Padang beserta segenap Staf Pimpinan, Karyawan dan Karyawati di STIE “KBP” Padang.Ibu Aminar Sutra Dewi,SE,M.Si sebagai Pembimbing dalam penulisan skripsi ini.Bapak dan Ibu Dosen yang telah memberikan ilmu yang berguna selama penulis melakukan perkuliahan di STIE "KBP" Padang.Temanteman dan semua pihak-pihak yang membantu penulis dalam menyelesaikan skripsi ini yang tidak dapat penulis sebutkan satu persatu namanya.

\section{DAFTAR PUSTAKA}

Afriyeni, A., \& Marlius, D. (2017). Analisis Pengaruh Harga Saham Perdana Terhadap Abnormal Return Yang Diterima Investor Studi Pada Bursa Efek Indonesia. https://doi.org/10.31219/osf.io/8z7hx

Afriyeni, A., \& Marlius, D. (2018). Analisis Pengaruh Informasi Prospektus Perusahaan Terhadap Initial Return Saham Pada Pasar Perdana Di Bursa Efek Indonesia. https://doi.org/10.31219/osf.io/kt6c4

Afriyeni, A., \& Marlius, D. (2019). Analisis Faktor-Faktor Yang Berpengaruh Terhadap Ketepatan Waktu Penyampaian Laporan Keuangan Pada Perusahaan Yang Listing Di Bursa Efek Indonesia. https://doi.org/10.31219/osf.io/rv4qf

Afriyeni, A., \& Marlius, D. (2019). Analisis Tingkat Pengembalian Dan Risiko Investasi (Studi Pada Industri Manufaktur Yang Terdaftar Di Bursa Efek Indonesia). https://doi.org/10.31219/osf.io/cfb92

Afriyeni, A., \& Fernos, J. (2019). Analisis Pengaruh Faktor Determinan Terhadap Economic Value Added Dan Implikasinya Terhadap Pergerakan Harga Saham Properti Di Bursa Efek Indonesia. https://doi.org/10.31219/osf.io/qf5nm

Dewi, ayu sri mahatma, \& Wirajaya, A. (2013). Pengaruh Struktur Modal, Profitabilitas dan Ukuran Perusahaan pada Nilai Perusahaan, 2, 358-372. https://doi.org/ISSN : 2302-8556

Dewi, A. S. (2015). Pengaruh Informasi Arus Kas Dan Earning PER Share Terhadap Return Saham Perusahaan Manufaktur di Bursa Efek Indonesia. Riset Manajemen Dan Akuntansi, 2, 1-7. 
Igusti Ngurah Agung Dwi Pramana, \& Mustanda, I. K. (2016). Pengaruh Profitabilitas dan Size terhadap Nilai Perusahaan dengan CSR sebagai Variabel Pemoderasi, 5(1), 561-594. https://doi.org/ISSN : 2302-8912

Manoppo, H., \& Arie, fitty valdi. (2016). Pengaruh Struktur modal, ukuran perusahaan dan profitabilitas terhadap nilai perusahaan otomotif yang terdaftar di bursa efek indonesia periode 2011 - 2014.

Moniaga, F. (2011). Struktur Modal , Profitabilitas, dan Struktur Biaya terhadap Nilai Perusahaan Industri Keramik,Porcelen dan Kaca Periode 2007-2011, 1(4), 433-442. https://doi.org/ISSN : 2303-1174

Prasetia, ta'dir eko, Tommy, P., \& Saerang, ivone s. (2014). struktur modal,ukuran perusahaan dan risiko perusahaan terhadap nilai perusahaan otomotif yang terdaftar di bei.

Rumondor, R., Mangantar, M., \& Sumarauw, jacky s. b. (2015). Pengaruh Struktur Modal , Ukuran Perusahaan dan Resiko Perusahaan terhadap Nilai Perusahaan pada Sub Sektor Plastik dan Pengemasan di BEI, 3(3), 159-169. https://doi.org/ISSN : 2303 - 11 